\title{
Effect of Spacing and Topping on Yield of Summer Sesame (Sesamum indicum L.)
}

\author{
Sanjay N. Shah, Hiren K. Patel* and Amit P. Patel
}

Department of Agronomy, B.A. College of Agriculture, Anand Agricultural University, Anand-388110, India

*Corresponding author

\section{A B S T R A C T}

\section{Keywords}

Topping, spacing, Sesame and yield

\section{Article Info}

Accepted:

18 April 2020

Available Online:

10 May 2020
The present investigation was conducted to study the effect of spacing and topping. The field experiment was carried out at College Agronomy farm, B.A. College of Agriculture, Anand Agricultural University, Anand during summer season of year 2017 and 2018. The soil of the experimental area was loamy sand in texture having in low available nitrogen, high in available phosphorus and medium in potash with soil $8.12 \mathrm{pH}$. The experiment consist of three spacing treatments $\left(S_{1}: 30 \mathrm{~cm}\right.$ between rows, $S_{2}: 45 \mathrm{~cm}$ between rows, $S_{3}: 60$ $\mathrm{cm}$ between rows) and four topping treatments $\left(\mathrm{T}_{1}\right.$ : No topping, $\mathrm{T}_{2}$ : Topping at $25 \mathrm{DAS}$, $\mathrm{T}_{3}$ : Topping at $35 \mathrm{DAS}$ and $\mathrm{T}_{4}$ : Topping at 45 DAS) was tested in split plot design with four replication. The results revealed that plant population and periodical plant height were significantly higher when crop was sown with $30 \mathrm{~cm}$ spacing between two rows $\left(\mathrm{S}_{1}\right)$.Effect of spacing was found non-significant in case of number of branches and stalk yield. Significantly higher seed yield $(1134 \mathrm{~kg} / \mathrm{ha})$ and the highest number of capsules/plant was found when sesame was sowning at $45 \mathrm{~cm}$ between two row. In case of topping treatment, topping done at 35 DAS $\left(\mathrm{T}_{3}\right)$ recoded significantly higher plant height, number of branches/plant, no. of capsule/plant, test weight and stalk yield.

\section{Introduction}

Sesame (Sesamum indicum L.) is one of the oldest spices and oilseed crops in the world and it was domesticated well over 3000 years ago. An India rank first in area (29\%), production $(26 \%)$ and export $(40 \%)$ of sesame in the world. Sesame seed provides excellent food, nutrition, health care, edible oil and biomedicine.
The production of oilseed crops in our country including sesame is not enough to meet the domestic demand of the large population.

In general, average productivity of sesame continues to be lower (144 to $234 \mathrm{~kg} \mathrm{ha}^{-1}$ ) than expected from agricultural technology for the last 20 years, mainly due to its cultivation during rainy season on marginal 
lands, under poor management practices. The average yield in summer season is remarkably higher than the yield of kharif season because kharif sesamum is often caught in rains at maturity resulting in discolored grains due to mould incidence and fails to attract export market.

Sesamum yield is the manifestation ofvarious physiological processes occurring in plants and they are usually modified by management practices viz., plant geometry, fertilization, terminal clipping (topping) etc. are most important factor for determining the yield. Spacing have distinct effect on the growth attributes viz., plant height and number of branches plant ${ }^{-1}$ as well as on yield and yield attributes viz., number of capsules/plant and number of seeds/capsule (Subrahmaniyan et al., 2001)

For Topping means removal or clip off terminal bud which activates the dormant lateral buds to produce a greater number of branches. In sesame, the development of auxiliary buds is inhibited by normally Indole Acetic Acid (IAA) produce in the apical meristem. If the source of auxin is removed by excising the apical meristem, the lateral branching gets accelerated moreover, terminal clipping also increases the net assimilation rate. Hence, lateral branches growth increases the surface area for photosynthesis and also increases the dry matter production. Terminal topping arrested growth of the plant which leads to greater chances for development of source to sink feature in sesame.

\section{Materials and Methods}

The present study was conducted at the College Agronomy Farm, Department of Agronomy, B.A. College of Agriculture, Anand Agricultural University, Anand388110 to study the effects of spacing and topping on yield of summer sesame during summer season of 2017 and 2018 on sandy loam soil. There were total twelve treatment combination, main plot having three levels of spacing $\left(S_{1}: 30 \mathrm{~cm}\right.$ between rows, $S_{2}: 45 \mathrm{~cm}$ between rows and $S_{3}: 60 \mathrm{~cm}$ between rows) and sub plot having four levels of topping $\left(\mathrm{T}_{1}\right.$ : no topping, $\mathrm{T}_{2}$ : Topping at $25 \mathrm{DAS}, \mathrm{T}_{3}$ : Topping at 35 DAS and $\mathrm{T}_{4}$ : Topping at 45 DAS). The experiment was laid out in Split plot design with four replication. The soil of experiment site was loamy sand with $8.12 \mathrm{pH}$, it was low in organic carbon $(0.27 \%)$, medium in available phosphorus (49.34 $\mathrm{kg} \mathrm{ha}^{-1}$ ) and high in available potash (317.79 $\mathrm{kg} \mathrm{ha}^{-1}$ ). Seasme variety GT 3 was used for experiment purpose.

All agronomical practices were followed for successful cultivation of crop. According to treatment, crop was sown in field and topping was done according to the treatments. The recommended dose of phosphorus @ $40 \mathrm{~kg}$ $\mathrm{ha}^{-1}$ was applied uniformly to all the treatments as a basal application. Half dose of nitrogen in form of urea was applied at basal application and remaining half dose of nitrogen applied after 30 DAS, remaining all deficient nutrients were applied according to initial soil status report. The collected data for various parameters were statistically analysed using Fishers analysis of variance (ANOVA) technique and the treatments were compared at 5\% levels of significance (Cochran and Cox, 1967).

\section{Results and Discussion}

\section{Effect of spacing}

Pooled data presented in Table 1 indicated that plant population recorded at 30 DAS and at harvest was significantly influenced by different spacing treatments. Significantly the highest plant population was observed in the treatment $S_{1}(30 \mathrm{~cm}$ spacing) at 30 DAS (354) and at harvest (338). 
Treatment $S_{1}$ registered higher plant population might be due to crop sown at narrow row spacing i.e. $30 \mathrm{~cm}$ leads to increase the number of plant per unit area while treatment $S_{3}$ recorded lower plant population may be attributed to crop sown at wider row spacing i.e. $60 \mathrm{~cm}$ responsible for lower number of plant per unit area. The higher plant population under narrow row spacing was also observed by Tahir et al., (2012).

Significantly higher plant height at 25 and 60 DAS and at harvest was observed (Table 1) in treatment $S_{1}(30 \mathrm{~cm}$ spacing $)$ in pooled analysis (21.93, 61.29 and 75.35, respectively). The increase in the plant height under narrow spacing treatment i.e. $\mathrm{S}_{1}$ (30 $\mathrm{cm})$ might be due to increase in number of plant per unit area there by strong competitions between the plant for utilization of space, sunlight, moisture and nutrient and to intercept the maximum sunlight for plant, thereby increase the height of the plant. Similarly, Sarma (1994) observed that in narrow spacing, plants compete more for available resources especially for light and resulted in more height than widely spaced plants in sesamum. Number of branches/plant recorded at 30 (2.19) and 60 (4.09) DAS and at harvest (4.87) was found significantly higher in the treatment $S_{2}(45 \mathrm{~cm}$ spacing) inpooled analysis (Table 1).

The higher number of branches/plant under wider geometry might be due to sufficient availability of vertical as well as horizontal space as a result more penetration of sun light and better absorption of nutrient and enhances the production of healthy primary and secondary branches as compared to narrow spacing. Moreover, under wider spacing congenial micro environment prevailed from its early growth stage which might have helped to put forth enhanced rate of growth and development of plant (Sivagamy and
Rammohan, 2013). Data presented in Table 2 indicated that treatment $S_{2}(45 \mathrm{~cm}$ spacing) recorded significantly the highest no. of capsule/plant (63.46). Higher number of capsules/plant under medium spacing $(45 \mathrm{~cm})$ compared to narrow spacing $(30 \mathrm{~cm})$ might be due to better geometric arrangement help in enhanced photosynthesis rate which consequently might have more diversion of photosynthate from source to sink as result more manifested capsules plant ${ }^{-1}$ (Sivagamy and Rammohan, 2013). Hemalatha et al., (1999) also found similar line of results which indicated that competition free environment enabling the crop for the use of growth limiting resources efficiently which contributed to improved crop performance. Liner response was observed in average number of days to maturity (79.33) and no. of seeds/capsule (67.07). Days to maturity under wider spacing treatment might be due less competition occurs in between plant hence, more nutrition are available in wider spacing which cause more vegetative growth as a result delayed time for flowering and maturity but its opposite phenomena occurred in narrow spacing because whenever any stress occurred plant speedily change their development stages from germination to maturity as a result lesser days required by the crop to reach maturity.

Perusal of data presented in Table 2 indicated that treatment $S_{2}(45 \mathrm{~cm}$ between two line) was recoded significantly the highest test weight (3.47) in pooled results. The variation in test weight was ascribed due to that in medium spacing proper nourishment of plant due to favorable plant environment like space, water, nutrients and sunlight without competition as a result increase the growth of individual plant and gain maximum weight of individual seed as compared to remaining spacing and another reason might be due to better availability of nutrients and better translocation of photosynthates to the seeds at 
properly spaced plants (Patel et al., 2014). Favorable effect of spacing was found significant in case of seed yield. Significantly higher seed yield (1134 kg/ha) was noted in medium space (45 cm between two row) treatment but it was statically at par with narrow space treatment $S_{1}(30 \mathrm{~cm}$ between two line). It was ascribed that under medium spacing proper arrangements of plant might have helped in better absorption of moisture and nutrients as well as efficient photosynthesis which ultimately lead to increased vegetative growth of the plant which resulted in better manifestations of higher value for all the yield contributing traits viz., plant population, higher number of branches/plant, number of capsules/plant and test weight. Non-significant effect of spacing was found in straw yield. Such type of results also reported by Roy et al., 2009 and Kumara et al., 2014.

\section{Effect of topping}

At 30 DAS, Topping at 35 DAS $\left(\mathrm{T}_{3}\right)$ recorded significantly higher plant population (271)but remained at par with the treatments of $\mathrm{T}_{1}$ (No Topping) and $\mathrm{T}_{4}$ (Topping at $45 \mathrm{DAS}$ ) and at harvest (Table 1) effect of topping did not reach to the level of significance.

The data presented in Table 1 showed that plant height of sesame recorded at 25, 60 DAS and at harvest was significantly affected by different topping treatments. Significantly the highest plant height $(20.25$ and $71.80 \mathrm{~cm}$, at 25 DAS and at harvest, respectively) and higher plant height $(56.83 \mathrm{~cm}$ at 60 DAS $)$ were measured in the treatment $\mathrm{T}_{3}$ (Topping at 35 DAS). Number of branches/plant (Table 1) recorded at $30,60 \mathrm{DAS}$ as well as at harvest was significantly affected by different topping. Significantly the highest number of branches/plant was observed in the treatment $\mathrm{T}_{3}$ (Topping at $35 \mathrm{DAS}$ ) at $60 \mathrm{DAS}$ (3.74) and at harvest (4.32), while significantly higher number of branches/plant at 25 DAS (2.17) but it was statistically at par with treatment $\left(\mathrm{T}_{4}\right)$. These might be due to topping during log phase where plant gains speed at logarithmic levels. In topping the apical portion of main stem was removed therefore, more side branches were formed below clipped portion. This may be due to the shoot tip rising from the shoot apical meristem inhibits the growth of the lateral bud by repressing auxin. When the shoot is cut off through terminal clipping, the lateral bud begins to lengthen which is mediated by a release of cytokinin. Once the apical dominance has been lifted from the plant, elongation and lateral growth is promoted and the lateral buds grow into new branches. Similarly, Singh et al., 2013 and Kamble et $a l ., 2015$ reported same result.

Topping treatments $\left(\mathrm{T}_{3}\right)$ was also influenced significantly for number of capsules/plant and number of seeds/capsule (Table 2). Significantly the maximum number of capsules/plant (59.20) and higher number of seeds/capsule (67.43) was noted in treatment $\mathrm{T}_{3}$ (Topping at $35 \mathrm{DAS}$ )in pooled analysis. The higher number of capsules/plant under topping treatment might be due to dispersion of carbohydrates or food material toward the auxiliary vegetative buds below clipped portion which in turn might have helped in production of more number branches plant ${ }^{-1}$ thereby more number branches plant ${ }^{-1}$ thereby more number of capsules plant ${ }^{-1}$ and another reason is that topping activated production of more number of branches which have enhanced uptake of nutrient as a result increase the horizontal growth of plant, more photosynthesis take place due to increased level of chlorophyll and providing plant with more food as a result more capsules plant under treatment $\mathrm{C}_{3}$. These results are in close agreements with the findings of Chandrashekharan (1992) Singh et al., (2013) and Kamble et al., (2015). 
Table.1 Effect of spacing and topping on growth attributes of sesmum (Pooled of Two year)

\begin{tabular}{|c|c|c|c|c|c|c|c|c|}
\hline \multirow[t]{2}{*}{ Treatment } & \multicolumn{2}{|c|}{ Plant population/plot } & \multicolumn{3}{|c|}{ Plant height (cm) } & \multicolumn{3}{|c|}{ No. of branches/plant } \\
\hline & At 30 DAS & At harvest & At 25 DAS & At 60 DAS & At harvest & At 30 DAS & At 60 DAS & At harves \\
\hline \multicolumn{9}{|l|}{ Spacing (S) } \\
\hline$S_{1}$ & 354 & 338 & 21.93 & 61.29 & 75.35 & 2.01 & 2.75 & 3.36 \\
\hline $\mathbf{S}_{2}$ & 249 & 234 & 20.13 & 56.35 & 70.47 & 2.19 & 4.09 & 4.87 \\
\hline$S_{3}$ & 182 & 173 & 16.03 & 44.52 & 59.82 & 2.09 & 3.72 & 4.07 \\
\hline S. Em. \pm & 5.81 & 5.27 & 0.33 & 1.04 & 1.08 & 0.04 & 0.06 & 0.17 \\
\hline C.D. $(\mathbf{P}=\mathbf{0 . 0 5})$ & 18 & 17 & 1.03 & 3.19 & 3.32 & 0.14 & 0.18 & NS \\
\hline CV \% & 12.56 & 12.01 & 9.76 & 10.84 & 8.89 & 12.27 & 9.76 & 10.38 \\
\hline \multicolumn{9}{|l|}{ Topping } \\
\hline$T_{1}$ & 267 & 253 & 19.12 & 54.16 & 68.10 & 2.12 & 3.48 & 4.07 \\
\hline $\mathbf{T}_{2}$ & 248 & 235 & 18.73 & 51.98 & 66.61 & 2.02 & 3.39 & 3.97 \\
\hline $\mathbf{T}_{3}$ & 271 & 259 & 20.25 & 56.83 & 71.80 & 2.17 & 3.74 & 4.32 \\
\hline $\mathbf{T}_{4}$ & 260 & 247 & 19.34 & 53.26 & 67.68 & 2.06 & 3.47 & 4.04 \\
\hline S. Em. \pm & 5.65 & 7.21 & 0.28 & 1.01 & 1.09 & 0.04 & 0.06 & 0.07 \\
\hline C.D. $(\mathbf{P}=\mathbf{0 . 0 5})$ & 16 & NS & 0.80 & 2.86 & 3.07 & 0.11 & 0.16 & 0.22 \\
\hline CV \% & 10.59 & 10.05 & 7.16 & 9.16 & 7.77 & 9.21 & 7.74 & 9.15 \\
\hline \multicolumn{9}{|l|}{ Interaction } \\
\hline $\mathbf{S} \times \mathbf{T}$ & Sig. & Sig. & NS & NS & NS & Sig. & NS & NS \\
\hline \multicolumn{9}{|l|}{ Year Effect } \\
\hline $\mathbf{Y}$ & NS & NS & Sig. & NS & NS & Sig. & Sig. & Sig. \\
\hline YXS & NS & NS & NS & NS & NS & NS & NS & NS \\
\hline $\mathbf{Y} \mathbf{X} \mathbf{T}$ & NS & NS & NS & NS & NS & NS & NS & NS \\
\hline Y X S X T & NS & NS & NS & NS & NS & NS & NS & NS \\
\hline
\end{tabular}

Table.2 Effect of spacing and topping on yield attributes and yield of sesmum

(Pooled of Two year)

\begin{tabular}{|c|c|c|c|c|c|c|}
\hline Treatment & $\begin{array}{c}\text { No. of } \\
\text { capsules/ } \\
\text { plant }\end{array}$ & $\begin{array}{l}\text { No. of seeds/ } \\
\text { capsule }\end{array}$ & $\begin{array}{c}\text { Days to } \\
\text { maturity }\end{array}$ & $\begin{array}{l}\text { Test weight } \\
\text { (g) }\end{array}$ & $\begin{array}{c}\text { Seed yield } \\
\text { (kg/ha) }\end{array}$ & $\begin{array}{c}\text { Straw yield } \\
(\mathrm{kg} / \mathrm{ha})\end{array}$ \\
\hline \multicolumn{7}{|l|}{ Spacing (S) } \\
\hline $\mathbf{S}_{1}$ & 47.36 & 60.83 & 79.33 & 3.30 & 1120 & 2435 \\
\hline $\mathbf{S}_{2}$ & 63.46 & 62.21 & 82.66 & 3.47 & 1134 & 2528 \\
\hline $\mathbf{S}_{3}$ & 56.63 & 67.07 & 84.91 & 3.34 & 1009 & 1978 \\
\hline S. Em. \pm & 1.01 & 1.18 & 1.21 & 0.03 & 22 & 124 \\
\hline C.D. $(\overline{P=0.05})$ & 3.11 & 3.65 & 3.74 & 0.09 & 66 & NS \\
\hline CV \% & 10.24 & 10.58 & 8.35 & 4.94 & 11.22 & 12.02 \\
\hline \multicolumn{7}{|l|}{ Topping } \\
\hline$T_{1}$ & 53.46 & 59.90 & 79.33 & 3.17 & 970 & 2062 \\
\hline$T_{2}$ & 56.34 & 64.85 & 83.74 & 3.41 & 1171 & 2416 \\
\hline$T_{3}$ & 59.20 & 67.33 & 85.74 & 3.57 & 1207 & 2506 \\
\hline $\mathbf{T}_{4}$ & 54.28 & 61.41 & 80.39 & 3.32 & 1003 & 2271 \\
\hline S. Em. \pm & 0.96 & 1.06 & 1.08 & 0.03 & 50 & 46 \\
\hline C.D. $(\bar{P}=0.05)$ & 2.70 & 2.98 & 3.06 & 0.07 & NS & 131 \\
\hline CV \% & 8.39 & 8.16 & 6.43 & 3.82 & 9.17 & 9.79 \\
\hline \multicolumn{7}{|l|}{ Interaction } \\
\hline $\mathbf{S} \times \mathbf{T}$ & NS & NS & NS & Sig. & NS & Sig. \\
\hline \multicolumn{7}{|l|}{ Year Effect } \\
\hline $\mathbf{Y}$ & Sig. & Sig. & NS & Sig. & Sig. & Sig. \\
\hline Y X S & NS & NS & NS & NS & NS & Sig. \\
\hline Y X T & NS & NS & NS & NS & Sig. & NS \\
\hline Y X S X T & NS & NS & NS & NS & Sig. & Sig. \\
\hline
\end{tabular}


Table.3 Interaction effect of spacing and topping on plant population at 30 DAS and at harvest

\begin{tabular}{|c|c|c|c|c|c|c|c|c|}
\hline \multirow{3}{*}{$\begin{array}{r}\text { Treatment } \\
\text { Spacing }(\mathrm{cm})\end{array}$} & \multicolumn{8}{|c|}{ Effect of topping } \\
\hline & \multicolumn{4}{|c|}{ Plant population at $30 \mathrm{DAS}$} & \multicolumn{4}{|c|}{ Plant population at harvest } \\
\hline & $\mathrm{T}_{1}$ & $\mathrm{~T}_{2}$ & $\mathrm{~T}_{3}$ & $\mathrm{~T}_{4}$ & $\mathrm{~T}_{1}$ & $\mathrm{~T}_{2}$ & $\mathrm{~T}_{3}$ & $\mathrm{~T}_{4}$ \\
\hline $\mathrm{S}_{1}$ & 359 & 286 & 338 & 433 & 349 & 262 & 228 & 418 \\
\hline $\mathbf{S}_{2}$ & 270 & 222 & 283 & 220 & 262 & 201 & 275 & 196 \\
\hline $\mathbf{S}_{3}$ & 172 & 237 & 191 & 125 & 151 & 240 & 174 & 128 \\
\hline S. Em. \pm & \multirow{2}{*}{\multicolumn{4}{|c|}{$\begin{array}{l}10 \\
28\end{array}$}} & \multirow{2}{*}{\multicolumn{4}{|c|}{$\begin{array}{c}9 \\
25\end{array}$}} \\
\hline C.D. $(\overline{P=0.05})$ & & & & & & & & \\
\hline
\end{tabular}

Table.4 Interaction effect of spacing and topping on no. of branches/plant and test weight at $30 \mathrm{DAS}$ and at harvest

\begin{tabular}{|c|c|c|c|c|c|c|c|c|}
\hline \multirow{3}{*}{$\begin{array}{r}\text { Treatment } \\
\text { Spacing }(\mathrm{cm}) \\
\end{array}$} & \multicolumn{8}{|c|}{ Effect of topping } \\
\hline & \multicolumn{4}{|c|}{ No. of branches/plant at 30 DAS } & \multicolumn{4}{|c|}{ Test weight (g) } \\
\hline & $\mathrm{T}_{1}$ & $\mathrm{~T}_{2}$ & $\mathrm{~T}_{3}$ & $\mathrm{~T}_{4}$ & $\mathrm{~T}_{1}$ & $\mathrm{~T}_{2}$ & $\mathrm{~T}_{3}$ & $\mathrm{~T}_{4}$ \\
\hline $\mathbf{S}_{1}$ & 2.21 & 1.89 & 2.11 & 1.83 & 3.10 & 3.47 & 3.46 & 3.16 \\
\hline $\mathbf{S}_{2}$ & 2.20 & 2.15 & 2.20 & 2.20 & 3.24 & 3.63 & 3.50 & 3.50 \\
\hline $\mathbf{S}_{\mathbf{3}}$ & 1.96 & 2.03 & 2.21 & 2.16 & 3.17 & 3.14 & 3.75 & 3.29 \\
\hline S. Em. \pm & \multirow{2}{*}{\multicolumn{4}{|c|}{$\begin{array}{l}0.07 \\
0.19\end{array}$}} & \multicolumn{4}{|c|}{0.05} \\
\hline C.D. $(P=0.05)$ & & & & & \multicolumn{4}{|c|}{0.13} \\
\hline
\end{tabular}

Table.5 Interaction effect of spacing and topping on stalk yield of sesame

\begin{tabular}{|c|c|c|c|c|}
\hline Treatment & & Eff & & \\
\hline & & stal & & \\
\hline Spacing (cm) & $\mathrm{T}_{1}$ & $\mathrm{~T}_{2}$ & $\mathrm{~T}_{3}$ & $\mathrm{~T}_{4}$ \\
\hline $\mathrm{S}_{1}$ & 2091 & 2266 & 2477 & 2904 \\
\hline $\mathbf{S}_{2}$ & 2375 & 2712 & 2889 & 2138 \\
\hline $\mathbf{S}_{3}$ & 1720 & 2269 & 2151 & 1771 \\
\hline S. Em. \pm & & & & \\
\hline C.D. $(P=0.05)$ & & & & \\
\hline
\end{tabular}

Topping treatments showed their significant influence in days to maturity recorded in pooled analysis (Table 2). Treatment $\mathrm{T}_{1}$ (No Topping) recorded significantly less number of days required for maturity. Treatment $\mathrm{T}_{4}$ required numerically more days due to topping the production of auxin plays a minor role in the initiation of flowering.

Topping treatments was significantly influenced on test weight in pooled analysis and treatment $\mathrm{T}_{3}$ (Topping at 35 DAS) recorded the highest test weight $(3.57 \mathrm{~g})$.
The results given in Table 2 showed nonsignificant influence of different treatments of topping on seed yield of sesame in pooled results. Significantly higher seed yield of $1207 \mathrm{~kg} / \mathrm{ha}$ was obtained in treatment $\mathrm{T}_{3}$ (Topping at 35 DAS).

Stalk yield of sesame was significantly affected due to different topping treatments during pooled analysis (Table 2). Treatment $\mathrm{T}_{3}$ (Topping at $35 \mathrm{DAS}$ ) being at par with treatment $\mathrm{T}_{2}$ (Topping at $25 \mathrm{DAS}$ ) recorded higher sesame stalk yield $(2506 \mathrm{~kg} / \mathrm{ha})$ in 
pooled results, Same line of results also reported by different scientists vis. Singh et al., 2013 and Kamble et al., 2015.

\section{Interaction effect}

The interaction effect of spacing and topping treatments in pooled analysis is presented here. Interaction effect of years and treatments of different characters are depicted in respective Table 3 to 5 .

Data presented in Table 3 indicated that significantly the highest plant population/plot of sesame were recorded in treatment combination of $\mathrm{S}_{1} \mathrm{~T}_{4}(30 \mathrm{~cm}$ spacing, topping at 45 DAS) at 30 DAS (433) and at harvest (418).

Data presented in Table 4 showed that treatment combinations of $\mathrm{S}_{1} \mathrm{~T}_{1}(30 \mathrm{~cm}$ spacing, no Topping) and $\mathrm{S}_{3} \mathrm{~T}_{3}(60 \mathrm{~cm}$ spacing, topping at $35 \mathrm{DAS}$ ) recorded higher number of branches/plant at 30 DAS (2.21). Perusal of data presented in Table 3 indicated that significantly higher test weight $(3.75 \mathrm{~g})$ was observed in the treatment combination of $\mathrm{S}_{3} \mathrm{~T}_{3}$ (60 $\mathrm{cm}$ spacing, topping at $\left.35 \mathrm{DAS}\right)$. Treatment combination of $\mathrm{S}_{1} \mathrm{~T}_{4}(30 \mathrm{~cm}$ spacing, topping at 45 DAS) recorded higher stalk yield (2904 kg/ha) of sesame during pooled analysis.

From the results of two years of experimentation, it is concluded that sesame crops was gown by used of spacing $45 \mathrm{~cm}$ between two row recoded significantly higher seed yield (1134 kg/ha) but response of topping was failed to exert significant influence on seed yield during experimentation period.

\section{Acknowledgements}

Authors are very much thankful to the Director of Research and Dean P.G.Studies,
Principal and Dean, B.A. College of Agriculture and Professor and Head, Department of Agronomy for guide and support to conduct the research program and obtain its significant findings.

\section{References}

Channabasavanna, A. S. and Setty, A. R. (1992). Response of sesamum (Sesamum indicum L.) genotype to plant densities under summer conditions. Indian Journal of Agronomy, 37(3): 601-602.

Cochran, W. G. and Cox, G. M. (1957). Experimental designs, John Willey and Sons. Inc., New York, 546-568.

Hemalatha, S., Jagannatham, A. and Rao, P. V. (1999). Effect of nitrogen fertilization and row spacing on growth and yield of sesamum. Journal of Oilseed Research, 16(1): 128-129.

Kamble, D. R., Jadhav, P. B. and Nagrare, I. M. (2015). Effect of nutrient and terminal clipping on growth and yield of summer sesamum (Sesamum indicum L.). Green Farming, 6(4): 721-725.

Kumara, B. H. P., Chittapur, B. M., Hiremath, S. M., Malligwd, L. H., Nadaf, H. L. and Koti, R. V. (2014). Effect of fertilizer levels and planting geometry on the performance of sesamum genotype. Karnataka Journal of Agricultural Science, 27(3):289-292.

Patel, H. K., Patel, R. M., Desai, C. K. and Patel, H. B. (2014). Response of summer sesamum (Sesamum indicum L.) to different spacing and levels of nitrogen under north Gujarat condition. International Journal of Agriculture Sciences, 10(1):336-343

Sarma, N. N. (1994). Response of sesamum varieties to levels of nitrogen and spacing. Annals of Agricultural Research, 15(1): 107-109.

Singh, B., Singh, S., Kumar, V. and Kumar Y. 
(2013). Nitrogen and nipping schedule for higher productivity of sesamum (Sesamum indicum L.) on aridisols of South-Western Haryana. Haryana Journal of Agronomy, 29(1\&2): 1-5.

Sivagamy, K. and Rammohan, J. (2013). Effect of sowing date and crop spacing on growth, yield attributes and quality of sesamum. IOSR Journal of Agriculture and Veterinary Science, 5(2): pp38-40.

Subrahmaniyan, K., Arulmozhi, N. and Kalaiselven, P. (2001). Influence of plant density and NPK levels on the growth and yield of sesamum (Sesamum indicum L.) genotype. Agriculture Science Digest, 21(3): 208-209.

Tahir, M., Saeed, U., Ali, A., Hassan, T., Naeem, M., Ibrahim, M., Rehaman, H. and Javeed, H. M. R. (2012). Optimizing Sowing Date and Row spacing for newly Involved sesamum variety. Pakistan Journal of Life Science, 10(1):1-4.

\section{How to cite this article:}

Sanjay N. Shah, Hiren K. Patel, and Amit P. Patel. 2020. Effect of Spacing and Topping on Yield of Summer Sesame (Sesamum indicum L.). Int.J.Curr.Microbiol.App.Sci. 9(05): 23122319. doi: https://doi.org/10.20546/ijcmas.2020.905.264 